\title{
Antropologia, Estudos Culturais e Educação: desafios da modernidade
}

\author{
Neusa Maria Mendes de Gusmão *
}

Resumo: Desde sempre a questão da diversidade e do contato cultural esteve presente na humanidade e, agora, coloca-se de modo intenso nas sociedades modernas. O que é novo é o questionamento das formas constituídas de explicação, cujas premissas teóricas parecem estar superadas como possibilidade de compreensão desse novo momento e dessa nova realidade. A questão assim colocada faz emergir um intenso debate em torno da produção do conhecimento, de seu alcance e seus limites, de modo a questionar as formas constituídas de saber e os campos disciplinares construídos na modernidade. No contexto desse debate, a análise das relações existentes entre Antropologia, Estudos Culturais e Educação, apresenta-se como desafio teórico da modernidade e como uma necessidade diante dos princípios e das práticas presentes na articulação entre o campo científico e o processo educativo na sociedade moderna.

Palavras-chave: Antropologia; Estudos Culturais; Educação; diversidade; cultura.

\section{Anthropology, cultural studies and education: challenges of our times}

\begin{abstract}
The issues of diversity and cultural contact have always been inherent to mankind, and are now very present in modern societies. A new element added to that is the questioning of constituted ways to explain things, and the theoretical premises of these new kinds of explanation seem to be outdated as possibilities of understanding this new moment and situation. When we put it like this, we have the surge of an intense discussion around the ways knowledge is produced, as well as its reach and limitations, with the questioning of the constituted kinds of knowledge and disciplinary fields built up by mankind. In this debate, the analysis of relationships between anthropology, cultural studies and education proves to be a theoretical challenge of modernity and also a need in face of the principles and practices in the articulation between the scientific field and the educational process in modern society.
\end{abstract}

Key words: anthropology; cultural studies; diversity; culture; education.

* Professora associada do Departamento de Ciências Sociais na Educação (DECISE), do Programa de Pós-Graduação em Educação — FE/UNICAMP — e da Pós-Graduação — Doutorado em Ciências Sociais (Antropologia) — do IFCH/UNICAMP. Livre-docente em Antropologia da Educação. Publicações: Diversidade, cultura e educação. Olhares cruzados. São Paulo: Biruta, 2003; Os filhos da África em Portugal. Antropologia, multiculturalidade e educação. Belo Horizonte: Autêntica, 2005; O visual e o quotidiano. Lisboa,PT: Imprensa de Ciências Sociais/ICS, 2008. neusagusmao@uol.com.br. 
O mundo, hoje, encontra-se em meio de intensas transformações. Falamos em união, integração econômica e cultural, superação de fronteiras com a criação de grandes blocos de tendência hegemônica, como União Européia, Mercosul e outros. O mundo se globaliza, a cultura se mundializa, os mercados se unificam. Grupos diversos se deslocam no tempo e no espaço e, no entanto, em diferentes espaços e latitudes, as particularidades se reafirmam, diferentes povos, grupos, regiōes e culturas reivindicam um lugar próprio e singular, fazendo de nosso tempo um tempo aparentemente esquizofrênico. É nessa esquizofrenia que o debate das diferenças se coloca, ganhando presença e significado. O debate é novo? Pode-se afirmar que não. Desde sempre a questão da diversidade e do contato cultural esteve presente na humanidade e, agora, coloca-se de modo intenso nas sociedades modernas. O que é novo é o questionamento das formas constituídas de explicação, cujas premissas teóricas parecem estar superadas como possibilidade de compreensão desse novo momento e dessa nova realidade. A questão assim colocada faz emergir um intenso debate em torno da produção do conhecimento, de seu alcance e de seus limites, de modo a questionar as formas constituídas de saber e os campos disciplinares construídos na modernidade.

A antropologia, como ciência da modernidade, coloca seu aparato teórico construído no passado, com possibilidade de, no presente, explicar e compreender os intensos movimentos provocados pela globalização: de um lado, os processos homogeneizantes da ordem social mundial e, de outro, contrariando tal tendência, a reivindicação das singularidades, apontando para a constituição da humanidade como una e diversa. Contudo, essa tradição é hoje alvo de controvérsias, na medida em que os fatos decorrentes da intensa transformação da realidade parecem não estar contidos em seus princípios explicativos. Nesse campo de tensão, defende-se que ora a trajetória da antropologia tem sido a de avaliar as diferenças sociais, étnicas e outras com a finalidade de proporcionar alternativas de intervenção sobre a realidade social de modo a não negar as diferenças; ora não seria a tradição antropológica suficiente para dar conta do contexto político das diferenças e, como tal, estaria superada em seus propósitos. Decorrentes do questionamento que afeta as ciências humanas de modo geral ainda na segunda metade do século XX, e em particular a antropologia, emergem outras perspectivas teóricas, dentre as quais se destacam os chamados estudos culturais, cuja definição se dá no interior das correntes ditas pós-modernas.

No contexto desse debate, a análise das relações existentes entre antropologia, estudos culturais e educação apresenta-se como desafio teórico da modernidade e como uma necessidade diante dos princípios e das práticas presentes na articulação entre o campo científico e o processo educativo na 
sociedade moderna. Em jogo, a busca do diálogo inter e transdisciplinar capaz de recuperar da modernidade o pensamento crítico para compreender as propriedades da vida social e resgatar a noção de cultura como noção crítica e engajada, ou seja, que entende a cultura como questão política. Neste ensaio, portanto, pretende-se observar as raízes mais antigas postas pela antropologia e considerar seu percurso, bem como as críticas já feitas sobre seu passado, em paralelo com a história de emergência dos estudos culturais, já que para ambos os campos a centralidade do conceito de cultura é fundamental.

\section{Antropologia e Educação: um pouco de história}

Segundo Paula Montero (2003), uma longa história está na base de construção da antropologia como campo científico, e essa história envolve duas categorias fundamentais: a idéia de Homem e a idéia de Cultura. Para a autora, hoje se faz necessário retomar tais conceitos, resgatando seus pressupostos e, a partir do diálogo com alguns autores, situar a contribuição da abordagem antropológica para a inteligência dos problemas contemporâneos. Diz ainda que é necessário rasgar o véu da inocência que recobre muitos dos pressupostos da disciplina e, com isso, resgatar seu papel político, em nada diferente de outras ciências.

A análise do lugar variável da antropologia, como campo disciplinar no passado e no presente, coloca em questão a dimensão política própria de qualquer ciência e não ausente da história e da prática dessa ciência nascida nos estertores do século XIX e no início do século XX. Nesse sentido, a afirmação de Benoît de L'Estoile, Federico Neiburg e Lygia Sigaud (2002) aponta sua natureza:

$\mathrm{Na}$ divisão de trabalho entre as ciências sociais, a antropologia especializou-se na descrição e na classificação dos grupos sociais freqüentemente tidos como primitivos, atrasados, marginais, tribais, subdesenvolvidos ou pré-modernos, definidos por sua exterioridade e alteridade em relação ao mundo dos antropólogos, ele próprio definido pela civilização, pela ciência e pela técnica. No entanto, o trabalho dos antropólogos só foi possível porque tais grupos já se encontravam submetidos ou em processo de submissão aos estados nacionais ou imperiais modernos, e eram objeto de políticas que compreendiam desde a preservação e a proteção até programas de transformação social planificada e, também, políticas repressivas. A participação dos antropólogos na elaboração e na implementação dessas políticas tem sido habitualmente objeto de consideraçóes morais e políticas, mas negligenciada do ponto de vista da análise sociológica (p.9). 
A fala desses autores é significativa, já que aponta para aspectos que, ao longo do tempo, tornaram-se "marcas registradas" da antropologia, porém, vista como sendo "toda" a antropologia. Trata-se de seu caráter descritivo e classificatório, necessário para a caracterização dos povos objetos da colonização entre os séculos XIX e XX, e que construiu o que no campo do conhecimento se denomina, hoje, como antropologia clássica. Esta apresentava, por seus princípios centrais, a noção de exterioridade e alteridade, apreendida, esta, como alienidade ${ }^{1}$. Nesse sentido, antropologia e antropólogos estavam inseridos num mundo marcadamente tido como civilizado, científico e técnico, no qual a tríade civilização, ciência e técnica, como elementos centrais da condição de sociedade e de modernidade, definiam e demarcavam a condição humana e a própria humanidade. O fazer antropológico, nessa medida, era o de submeter e colocar em submissão o outro e seu mundo, tendo por meta a civilização e a humanidade. A antropologia como ciência pregava, então, a preservação, a proteção, a transformação e a repressão como objeto de políticas dirigidas ao mundo do outro. Nesse sentido, a participação dos antropólogos e a ciência que praticam acontecem na elaboração e na implementação dessas políticas, o que, mais tarde, já no início do século XX, será conhecido como uma ciência da prática ou uma ciência de serviço. ${ }^{2} \mathrm{O}$ que está em jogo nesse tipo de ciência são as relações entre ciência e prática, até hoje, fato de constantes discussóes no mundo científico e social. Expressiva desse tipo de prática científica e, posteriormente, objeto de considerações morais e políticas, como toda ciência praticada naquele período, inscreve-se em um campo particular da antropologia - a chamada antropologia "da" educação.

O campo da antropologia da educação foi bastante ativo entre os anos de 1920 e 1930 e assim persistiu durante todo o século XX, mudando sua roupagem (e muito pouco seu conteúdo) de acordo com as conjunturas sociais e políticas de cada momento. Significativa nessa antropologia foi a tentativa de "normalizar" os sistemas educativos, em busca de uma "funcionalidade" entre a escola e a sociedade, segundo um modelo "desejável" de escola. Tal perspectiva admitia, porém, a educação além da escola, pois dizia respeito à formação da

1. Alienidade é entendida como a alteridade distante em que "viajantes, comerciantes, conquistadores, missionários, fugitivos, etc." relatam a existência do "outro" no mundo europeu, revelando estranhamento quanto a sua existência social. (Santamaria, 1998, p.55)

2. Balandier (198I) chama de "ciência de serviço" a ciência de caráter aplicado cuja perspectiva é interventiva e justificada como de natureza ética (em nome do outro, de seu bem-estar, para seu desenvolvimento, etc.). Visa fornecer às administrações públicas do passado e do presente, elementos para medidas de intervenção sobre realidades vistas como "problemas" carentes de solução. Constituída sob a égide do funcionalismo dos anos de 1920/1930, retorna no final do século XX, com vistas a dar elementos para políticas sociais multiculturais, também de cunho intervencionista. Ver, também, Bastide (197I). 
personalidade e à socialização dos indivíduos, necessárias à integração e à acomodação à sociedade e a seus valores. $\mathrm{O}$ centro de sua razão de ser estava, portanto, na relação indivíduo-sociedade, típica do conhecimento daquela época que, anos mais tarde, em meados dos anos de 1950/1960, seria questionado como forma de conhecimento no campo científico. A intersecção e a crítica das relações indivíduo-sociedade e, posteriormente, a compreensão dos indivíduos como sujeitos sociais, iriam desencadear um debate entre as formas universais de compreensão da humanidade e as particularidades dos sujeitos, grupos e culturas. O fato, já no final dos anos de 1990, levará à revisão do conhecimento científico produzido pela modernidade na busca por formas alternativas de conhecimento e seria designado como "crise dos paradigmas". Tal movimento, em toda segunda metade do século XX, irá colocar a antropologia em geral e, em particular, a antropologia na educação ${ }^{3}$ como alvo das críticas que fariam emergir outras perspectivas de conhecimento, entre essas, os estudos culturais.

Em razão desse contexto, no presente ensaio, busca-se demonstrar que as críticas morais e políticas feitas a partir de uma parcela do que foi e é a antropologia gestaram uma cegueira na contribuição desta para com a educação. Ao mesmo tempo, a educação reeditou nos anos de 1990, nas abordagens do multiculturalismo, particularmente americano, os mesmos percalços da chamada ciência de serviço da primeira metade do século que passou e da qual a antropologia da educação foi representativa. Como dizem L'Estoile, Neiburg e Sygaud, se a ciência antropológica foi alvo de muitas críticas morais e políticas, não foi, contudo, objeto privilegiado do ponto de vista da análise sociológica, vale dizer, da análise mais crítica e analítica. Sem dúvida, tal ausência repercutiu, também, nas especialidades de seu campo, entre elas, a antropologia da educação. Desse movimento geral resultaram equívocos e limites na compreensão da antropologia, de seus métodos e de suas categorias ou noções centrais, entre elas, a noção de cultura e seu campo explicativo.

Nesse contexto, importam, aqui, as relações entre a educação e a antropologia, em particular aquela que emergiu ao final dos anos de 1980/1990, marcada pela institucionalização e pela generalização de um novo campo disciplinar: os estudos culturais. No interior desse novo campo, surgiu como fundamental o rechaçar da antropologia, vista apenas na sua dimensão clássica, sem considerar

3. Deve-se observar que Antropologia da Educação e Antropologia na Educação referem-se a assuntos correlatos, porém diversos. A primeira expressão diz respeito a um período histórico determinado, primeira metade do século $X X$, e a uma corrente teórica vinculada ao culturalismo e ao funcionalismo no trato das questões educacionais; é, assim, temporalmente situada. A segunda expressão remete às relações possíveis entre antropologia e educação, sem estar limitada a uma abordagem específica e temporalmente situada. Trata-se do diálogo entre campos de conhecimento diversos e suas possibilidades. 
sua dinamicidade e a própria revisão de muitos limites que por mais de um século atuou de modo a modernizar seu campo teórico e sua prática como ciência, ainda no interior do século XX e, portanto, da modernidade. A multiculturalidade - fato constatável da realidade social - que afeta as sociedades modernas, desde sempre presente para a ciência antropológica e para seus adeptos, os antropólogos, passou a integrar um debate que se definiu a partir do chamado multiculturalismo ${ }^{4}$, ou seja, de um campo que pretende explicar a diversidade social, em termos de teoria e prática.

Rocha-Trindade (1995), ao olhar o mundo europeu de hoje, afirma que o multiculturalismo se expressa em pelo menos duas acepções: como fenômeno observável na maioria das sociedades, a que corresponde um evidente pluralismo cultural resultante da intensificação e da posterior radicação de correntes migratórias de diferentes origens geográficas; e como um conjunto de políticas aplicadas em vários setores da administração pública, nomeadamente na educação, na formação profissional, no emprego e na ação social, com o propósito de responder aos requisitos específicos das sociedades plurais. No primeiro caso, vincula-se diretamente a heterogeneidade do social aos processos migratórios (recentes), e dele decorre a segunda acepção, ou seja, a do multiculturalismo como política aplicada. Muitas são as divergências a respeito dessa postura, já que todas as sociedades são multiculturais no tempo e no espaço; contudo, como diz Provensal, citada por Gusmão (2005), só no mundo moderno e contemporâneo é que o multiculturalismo se tornou uma forma de invenção e intervenção social.

Nesse sentido, a diversidade social, objeto basilar da ciência antropológica, passou, sob a égide do multiculturalismo, a ser considerada a partir de outros parâmetros e postulou como necessária a revisão do conceito de cultura, que deve ser, agora, inserido numa dimensão política que, teoricamente, foi originalmente negada pela antropologia. Vale, portanto, resgatar a citação de L'Estoile, Neiburg e Sygaud, quando dizem que desde sempre os grupos obje-

4. O multiculturalismo não nasceu nesse período ou mesmo na segunda metade do século $X X$, como se postula em muitos textos, principalmente no campo da educação. A concepção do multicultural e do multiculturalismo surgiu com alunos de Ruth Benedict e de Margaret Mead, M.Herkovits, R. Redefild e C. Kluckhohn, ainda nos anos 1940, motivada pelo crescente reconhecimento da diversidade social humana, exposta por duas guerras mundiais e pelas lutas de libertação dos povos coloniais. Contudo, não se trata ainda de uma perspectiva crítica em profundidade. Caberia, também, distinguir a diferença entre os termos - multiculturalidade (fato constatável que abrange toda a diversidade humana) e multiculturalismo (abordagem que intenta explicar a multiculturalidade e propor formas de intervenção em contexto multicultural) - e explorar como, quando e por que são tratados como sinônimos; a razão disso e suas conseqüências, quando se trata de pensar (e propor intervenção) na realidade concreta de povos, grupos, segmentos de grupos, etc. 
to do olhar do antropólogo "já se encontravam submetidos ou em submissão aos estados nacionais ou imperiais modernos" (2002, p. 9). O que os autores apontam é que o espaço por excelência de constituição e de atuação dessa ciência, a antropologia, e seu instrumento maior de explicação das realidades que estuda - a noção de cultura - nunca poderiam ser pensados fora do campo político e de poder. Para o autor, a noção de cultura sempre foi e é, portanto, uma noção que se define eminentemente como política. Essa a idéia central que conduz o presente ensaio a refletir sobre os desafios da modernidade nas relações entre antropologia, estudos culturais e educação, na pretensão de propor alguns caminhos de superação dos muitos véus que recobrem vários dos pressupostos da disciplina e de, com isso, resgatar seu papel político, como diz Montero (2003).

Desvendar esse processo pode contribuir para superar os vazios que permanecem no campo dos estudos culturais e que, muitas vezes, reeditam falhas já superadas do passado da antropologia. Nesse sentido, alguns dos princípios que os estudos culturais (americanos) postulam como necessários à compreensão e à defesa de diferentes grupos portadores de especificidades, ou a suas causas, resultam num perigo interpretativo de sérias conseqüências tanto para a ciência que se produz como para as formas de intervenção que são propostas sobre a realidade. Trata-se da indefinição da noção de cultura, principalmente quando essa noção se aproxima demasiadamente da concepção de ideologia. $\mathrm{O}$ perigo coloca-se com mais evidência quando ocorre uma dada premência em buscar "soluçôes", tomando por meta certo ativismo, quando este deveria servir de combustível da reflexão teórica e, assim, propiciar o desvendamento das grandes questóes para agir de modo mais eficaz na realidade dos grupos que se quer defender. Deve-se ressalvar, porém, o valor e a importância das perguntas que os estudos culturais e os estudos pós-modernos colocam, mas sem negar à antropologia seus créditos. É preciso olhar para essa ciência e compreender, com ela e a partir dela, os erros e os acertos do passado e, assim, não reproduzir, hoje, muitas das falhas daquele momento na compreensão da diversidade social humana. Fato que a própria antropologia já reconheceu e criticou e que, no entanto, não está longe de se repetir nos estudos atuais e, em particular, no campo da educaçãa, sob a égide dos estudos culturais.

Portanto, considera-se que as relaçóes entre antropologia, estudos culturais e educação resultam num campo tensional que diz respeito a duas dimensões correlacionadas: os paradigmas científicos da modernidade e da chamada pósmodernidade e os paradigmas pedagógicos que norteiam a educação. Por sua vez, as relações entre antropologia e educação fazem-se, também, como um campo de relações perigosas, já que envolvem a necessidade de considerar: 
- que toda ciência é conhecimento vinculado ao movimento da história e seus contextos;

- que os caminhos de encontro e desencontro da antropologia e da educação, eles próprios históricos e datados, constituem um campo de confrontação no tempo, entre um passado e um presente do conhecimento científico que norteia nossa compreensão de mundo 5 .

A antropologia como ciência preocupa-se com a questão das diferenças e busca propor formas de intervenção sobre a realidade, papel a que se dirige qualquer conhecimento produzido a partir das relaçóes entre os homens e o mundo social criado por eles. Talvez, por essa razão, Manuela Carneiro da Cunha (1998) tenha chamado a atenção para o fato de que não são as culturas que criam as sociedades, mas são as sociedades que criam as culturas. Assim, torna-se necessário o desvendar da sociedade onde se está e onde se vive, para compreender os dispositivos da cultura ou das culturas que operam nesse contexto. Contudo, as relaçóes entre os homens, constitutivas da vida em sociedade, são, sempre, profundamente heterogêneas e marcadas por relações de poder socialmente construídas. Dessa forma, a constituição de um campo de tensão entre sujeitos sociais diversos expõe ao pensamento e à prática antropológica três grandes processos inerentes às sociedades modernas: a) busca permanente pela homogeneização; b) existência da contradição; c) a ameaça constante do conflito.

Esses três processos resultam da cultura ocidental que se move em torno da busca permanente de fazer do outro, do diferente, um mesmo. Assim, a realidade das chamadas sociedades modernas, complexas e acentuadamente diversas, transforma-se num desafio ao pensamento, ao conhecimento e às práticas sociais que envolvem as diferenças sociais, de raça, étnicas, de gênero, econômicas, etárias e outras. Os considerados menos, porque diferentes - homens, mulheres, idosos, negros, indígenas - passam a desafiar a ordem instituída, e esta coloca sobre eles "certo dispositivo de saber sobre o outro, um saber sociológico sobre o outro que não se dissocia de um poder sobre o outro" (Santamaria, 1998, p. 56). A antropologia, nascida da sociedade ocidental portadora dessas características, não se dissocia de sua natureza, caminha com ela e constrói um percurso que vai da alienidade em relação ao outro à plena descoberta e ao comprometimento com esse outro. Transforma-se e institui a alteridade como a questão propulsora de si mesma como ciência, como fazer científico. E o faz pelo estranhamento do social, em razão da percepção e das evidências do mundo social e histórico. E o faz, posto que a existência social do outro, do nosso

5. Ver, a respeito, Gusmão (1997, p. 8-25). 
outro, revela ser este sempre próximo e diverso, sempre presente na constituição do nosso próprio mundo, do nosso próprio eu.

A descoberta instaura o desafio pelos acasos da vida cotidiana entre pessoas e marca o senso comum com que cada um elabora sua percepção de mundo. Por outro lado, exige da antropologia como ciência a construção de um saber assentado num modo de proceder ou de fazer ciência que pode reduzir, coisificar o outro e que esteve muito presente na sua origem, mas resultou numa série de procedimentos que colocaram em jogo a descoberta e a reflexão do nosso etnocentrismo e dela própria como ciência. Mais que isso, instaurou a necessidade de desconstruir pressupostos a priori para efetivamente construir uma explicação mais compreensiva e analítica das realidades sobre as quais se debruça como ciência. Como diz Santamaria (1998), em questão a necessidade de impensar as categorias com que apreendemos o mundo à nossa volta, para compreendê-lo de outra forma. Assim,

Impensar é refletir de modo a explicitar as condições e os modos que constantemente informam, mobilizam, dispōem, estruturam e instituem nossa percepção, nosso modo particular de olhar os seres e as coisas e conseqüentemente a formulação epistêmica que orienta nossas açōes e pensamentos. (Santamaria, 1998, p. 59)

Para realizar tal empreitada, qualquer busca de explicação da realidade exige:

- contextualizar a realidade dos sujeitos onde estão e vivem;

- inverter o olhar deles (e o nosso) para com a sociedade em que eles (e nós) estão;

- ver como essa sociedade se refere a esses sujeitos;

- pôr em questão o conhecimento que produzimos e a ciência que praticamos.

Diante desse desafio, diz Santamaria (1998):

todo conhecimento da realidade social não se reduz a uma mera operação cognitiva, mas é também, como nos adverte Bourdieu, uma operação sócio-política que sempre implica um reconhecimento e ou um desconhecimento daqueles sobre os quais se quer conhecer; daqueles a quem se quer conhecer (p.48)

Desentranhar esse universo cognitivo e sociopolítico exige tomar o campo da antropologia como ciência hoje, para perguntar sobre as categorias de apreensão e explicação da realidade, construídas no tempo. Exige não ignorá-las, mas fazer-lhes a crítica e buscar construir um conhecimento de outra ordem, como já o fez ela própria no percurso de sua constituição e história como ciên- 
cia, em outro momento no passado. Só assim será possível o diálogo e o confronto dos avanços e dos limites da antropologia na educação, em particular no campo de sua prática, a pedagogia, compreendendo aí a dimensão política desse campo de conhecimento e o significado disso que se denomina, hoje, como estudos culturais. Em jogo, a natureza própria de cada um dos campos e a história que os constitui. Em jogo, os caminhos trilhados pela antropologia e pela pedagogia desde o século XIX, que envolvem os paradigmas científicos e os paradigmas pedagógicos. Em questão, o conhecimento moderno constitutivo do campo científico e a natureza de intervenção prática subordinada ao ensino por parte de certo tipo de educação da qual somos todos herdeiros na sociedade moderna, vale dizer nas sociedades ocidentais centradas nas idéias de progresso e desenvolvimento. Sociedades nas quais ainda prevalece a tríade civilização, ciência e técnica como elementos centrais da condição de sociedade e de modernidade.

\section{A ciência que praticamos: a modernidade em debate}

As falas de Montero e de L'Estoile, Neiburg e Sygaud, já citadas, olham a antropologia à luz das ciências sociais, e é esse olhar que conduz a presente reflexão, já que esses autores entendem que essa ciência só pode ser compreendida em termos da história e, em particular, da história da antropologia. Nesse sentido, Montero, ao resgatar a categoria de Homem, tem por base as chamadas ciências positivistas do século XIX. Da mesma forma, a categoria Cultura é pensada como emergente da constituição das chamadas humanidades, ainda sob a égide do positivismo e que originou as diferentes ciências humanas, entre elas, a antropologia como ciência do homem. Montero propõe a retomada das categorias para situar as contribuiçôes da antropologia para a abordagem dos problemas contemporâneos e tem em mente o resgate do papel político da ciência antropológica. Por sua vez, L'Estoile, Neiburg e Sygaud retomam o fazer antropológico, inerente ao período positivista - o descrever e classificar que resultam do contato com outros povos no período colonial —, para reafirmar o papel político da antropologia e dos antropólogos desde a origem do seu fazer científico. $\mathrm{O}$ insistir na natureza política da antropologia significa afirmar a impossibilidade de a cultura ser uma noção apolítica, apenas descritiva e classificatória, até mesmo porque, como afirmam os três autores, a antropologia como ciência nasceu sob a égide dos estados nacionais ou imperiais modernos. $\mathrm{O}$ fato exige reflexôes críticas e análise criteriosa, e não avaliaçôes morais e políticas despregadas do contexto histórico.

Assim, a cultura como matéria-prima da antropologia não é um dado, uma herança, algo que se tem e que se herda como diz Cuche (1999), mas é uma 
construção que se inscreve na história das relações dos homens entre si. Tais relaçôes decorrem do contato e do jogo de distinção que, historicamente, estabelecem as diferenças culturais entre um eu e um outro. Nesse sentido, "as culturas nascem de relações sociais que são sempre desiguais" (Cuche, 1999, p. 243), de modo que as hierarquias culturais resultam da hierarquia social existente. Assim, para o autor, a cultura de um grupo não é independente de outro grupo que com ele se defronta, e nesse confronto criam um campo de tensão, às vezes de violência e de conflito, que expressa relações de poder imersas num campo político que deve ser considerado. Por essa razão, a não-consideração desses pontos, em termos das teorias do passado e do presente, leva a que não se compreenda a extensão, o alcance e os limites da ciência que hoje praticamos. Como diz Kuper (2002, p. 309), "as teorias modernas sobre cultura reciclam as anteriores e se prestam a propósitos políticos semelhantes”. Este o desafio necessário de confrontar e fazer dialogar a antropologia e os estudos culturais, nomeadamente, no campo da educação.

O diálogo, porém, debate-se entre o que herdamos das teorias do passado e o que buscamos no presente. Assim, Gilberto Velho (1997) fala-nos da tradição da antropologia no estudo da cultura das sociedades de pequena escala e o desafio que se interpõe na análise da cultura, quando a antropologia, sobretudo a antropologia moderna, migra para os contextos urbanos das chamadas sociedades complexas. Tais sociedades, marcadas pela heterogeneidade, pela multiplicidade de experiências, costumes e práticas, desafiam o olhar e o fazer antropológico em razão da afirmação constante da individualização, da multiplicidade das experiências humanas e da necessidade de universalização dessas experiências em nome de uma realidade mais homogênea e necessária a esse contexto. A ciência que praticamos é, então, desafiada no sentido de estabelecer pontes e fazer dialogar o particular (seu objeto no passado) com o universal e mais geral das sociedades modernas. Igualdade e diferença se fazem então, categorias referenciais por excelência; contudo, revelam-se não como categorias absolutas ou relativas como no passado, mas, sobretudo, como categorias relacionais, cuja definição exige compreender as relações em jogo e os processos de poder e de dominação que, no passado e no presente, geraram e geram marginalidade e exclusão.

A antropologia, como ciência surgida no século XIX, ainda hoje transita entre as forças perturbadoras do saber científico (positivista) e a necessidade de sua superação, contudo, sem romper de modo absoluto (como, aliás, todas as demais ciências de nosso tempo) com o modelo de racionalidade do que se convencionou chamar de ciência e o que se considerava, então, senso comum. A razão está em que a antropologia nasceu das chamadas humanidades, vista na passagem do século XIX e XX como uma não-ciência ou como uma ciência 
menor por não estar inteiramente definida pelos parâmetros científicos da época. No entanto, por sua trajetória e por sua prática, que resultam no trabalho de campo e na interação com o outro, a antropologia e o antropólogo passam a constituir um espaço de fronteira em que não se ajustam plenamente ao modelo científico predominante, nem se fazem alheios a esse modelo. A contradição que marcou, então, a emergência e a consolidação dessa ciência passa a ser o maior potencial de sua transformação, já na passagem do século XIX para o século XX.

Contudo, ao confrontar-se com as contradiçōes decorrentes desse fazer científico, a antropologia rompeu ou deu continuidade ao saber estabelecido? Mais do que isso, passados quase dois séculos, no advento do século XXI, a ciência que praticamos - seja ela a antropologia, os estudos culturais ou outra - consiste numa ruptura ou numa continuidade do conhecimento estabelecido e legitimado como ciência, desde o século XIX?

Como diz Vieira (2000, p. 83):

É sabido que o século XX foi praticamente dominado pelo paradigma cartesiano do primado da razão. Do elogio da razão e da crítica da emoção. Somos todos filhos dessa escola criada por Descartes, à volta da dúvida metódica e do primado racionalista. Viveu entre 1596 e 1650, mas as suas idéias mantiveram-se praticamente intocáveis e, de pé, até o século XXI.

Perante esse desafio, vozes insurgentes falam do fim da história ${ }^{6}$, de crise dos paradigmas e instituem outras formas de pensar as realidades modernas, questionando o pensamento clássico que originou o campo científico da modernidade. Com respeito ao fim de um tempo de longo prazo (típico da ciência positivista centrada na noção de futuro e de progresso) e ao seu colapso no curto prazo (entendido este como o final do século XX e o advento da pós-modernidade, que não reconhece o passado nem o futuro), Santos (1997) fala na necessidade de buscar no passado a "capacidade de fulguração e revelação no presente", para a construção de uma outra teoria da história. Adaptando e adequando ao nosso debate as palavras de Santos, este trabalho propóe que o passado da ciência antropológica seja revisitado, para nele (e, portanto, na modernidade) buscar sua "capacidade de fulguração e revelação no presente”, tal como sugere Montero (2003), ao postular a capacidade explicativa da antropologia para os fenômenos contemporâneos. Trata-se de ver a ciência antropológica não naquilo que simplesmente foi, mas no que ela e sua história

6. A referência diz respeito a Francis Fukuyama e a sua Teoria do Fim da História citado por Boaventura de Souza Santos em A queda do Angelus Novus. Para além da equação moderna entre raízes e opções". (1997, p. 103-124). 
podem nos proporcionar para olhar o nosso tempo e sobre ele estabelecer explicaçôes possíveis.

Mais uma vez, inspirada por Santos e por seu texto "Ângelus Novus" (1997), trata-se de não negar a modernidade em prol da pós-modernidade, como tem ocorrido nos emergentes debates de novos paradigmas, mas de reconhecer, na estrutura da ciência que praticamos, elementos fundamentais de construção de uma nova compreensão de mundo. Trata-se de não seguir a corrente, jogando a criança com a água do banho, mas de colher, nas teorias produzidas pela modernidade, elementos fundamentais para avançar o pensamento e não reproduzir erros e limitaçóes do passado. Assim, o que têm a dizer as teorias do passado da antropologia? Particularmente, o que dizem com relação à educação e sua prática - a pedagogia?

\section{O caminhar entre dois séculos - do XIX ao XX}

Os caminhos trilhados pela antropologia e pela pedagogia como campo prático da educação no período colonial, do século XVIII ao início do século XX, tiveram como alinhamento teórico a ciência evolucionista, cuja história diz respeito aos paradigmas científicos do pensamento moderno. A pedagogia, como intervenção prática, subordinava a educação ao processo de ensino, visando "modelar" o chamado diferente ao modelo ocidental, branco e cristão. Tratavase de fazer evoluir e civilizar os chamados "outros", sujeitos do processo colonial. Ao mesmo tempo, a ciência antropológica, inspirada pelos mesmos princípios de ordem e em acordo com as Ciências Naturais da época, buscava compreender o "outro" colonial dentro da escala evolutiva de uma humanidade única e homogênea. Ambas, a antropologia e a pedagogia tinham por referência a unidade da condição humana e a centralidade da noção de homem forjada pela ciência de seu tempo e em consonância com o modo de ser do europeu, colonizador. Havia, assim, um modelo de humanidade e um modelo de homem a definir os caminhos da civilização e a possibilidade de evolução e progresso daqueles que ainda não teriam a condição plena de ser humano. Nesta perspectiva do chamado evolucionismo linear, a cultura não tinha presença e, como tal, a diversidade do ser humano não encontrava lugar, a não ser como uma etapa necessária do desenvolvimento e do progresso da humanidade, representada num gradiente único, necessário e obrigatório em qualquer tempo e espaço.

Principal teórico do evolucionismo, L. Morgan será questionado por seu aluno F. Boas, que introduziu a perspectiva particularista da história da humanidade - história cultural ou culturalismo -, na tentativa de responder a heterogeneidade do social revelado por outros povos e culturas não européias tornadas visíveis pela realidade colonial. Ainda no século XIX, Boas será um 
dos primeiros cientistas a chamar a atenção para o fato de que não existe "cultura” e, sim, culturas. Dirá, também, que cada costume, hábito ou valor só poderá "ser explicado se relacionado ao seu contexto cultural" (Cuche, 1999, p. 45). O culturalismo ganhará força no princípio do século XX e terá, como uma de suas marcas, a denúncia do olhar etnocêntrico do momento anterior, presente, tanto na antropologia como na pedagogia que orientava os sistemas de ensino, em particular na sociedade americana de então. Nessa nova forma de olhar a realidade, emergiu com força uma concepção de cultura até então ausente das teorias vigentes e que iria reconhecer que cada cultura tem uma história própria e singular, de modo a permitir caminhos diversos para a humanidade, que assim se faz plural e diversa. Com isso, a biologia e as ciências naturais deixaram de ser o alicerce das reflexões sobre as diferenças, para colocar tal encargo como de responsabilidade da cultura.

Como afirma Geertz (1978 p. 47),

a imagem de uma natureza humana, constante, independente de tempo, lugar e circunstância, de estudos e profissōes, modas passageiras e opiniōes temporárias, pode ser uma ilusão, que o que o homem é pode estar tão envolvido com onde ele está, quem ele é e no que acredita, que é inseparável deles. É precisamente o levar em conta tal possibilidade que deu margem ao surgimento do conceito de cultura e ao declínio da perspectiva uniforme do homem.

Assim, a diversidade sociocultural dos povos coloniais permitiu o aprofundamento das críticas ao evolucionismo, denunciou seu etnocentrismo, fazendo com que a alienidade (o outro de meu mundo como não humano) do momento anterior fosse superada pela descoberta inicial da alteridade (o outro está no meu mundo e existe em relação a ele). Apesar da não plena consciência do outro, há, no interior desse pensamento, o reconhecimento da condição humana do outro, ainda que dele pouco ou nada se conheça.

O que importa é que, ao alvorecer do século XX, a antropologia já apontava para a impossibilidade de argumentar em torno de etapas necessárias e biologicamente definidas para a condição humana. Afirmava que a condição humana só poderia ser pensada no interior da cultura e assegurava como centro de seu olhar e de seu fazer o conceito de cultura. Cultura como realidade múltipla, plural e diversa. Prenunciava, assim, outra compreensão de mundo e suas muitas possibilidades, mas o avanço que esse passo representava era ainda limitado, posto que marcado por extrema relativização, o culturalismo assume cada cultura como totalidade em si mesma. No mundo há, então, culturas múltiplas e diversas, porém, que não são vistas como realidades insurgentes do contato e em relação a um contexto histórico determinado. 
Contudo, apesar das mudanças em curso no conhecimento estabelecido (outras ciências além da antropologia emergiram, constituindo as chamadas Humanidades), os sistemas educativos e os mecanismos pedagógicos desse tempo ainda seguiam as diretrizes de uma educação pautada por um modelo único, ao qual a instituição escolar estava submetida. É desse momento a conhecida denúncia de Boas sobre as escolas americanas e seu sistema de ensino. Em torno de 1909, dizia ele:

a escola inexiste como instituição independente e, como tal, não possibilita independência e autonomia aos sujeitos que aí estão. A meta da escola centra-se num aluno-modelo que desconsidera a diversidade da comunidade escolar e, para contêla, atua de forma autoritária. (Gusmão, 1999, p. 19).

A afirmação, em muito válida ainda hoje, mostra a homogeneidade presente como meta, que não permitia à escola o reconhecimento da diversidade social que adentrava o sistema escolar. Se no campo da educação e sua prática tal não acontecia, no campo da antropologia algo começava a mudar em direção à consolidação de uma visão plural de mundo e de uma concepção relativista da cultura.

Assim, o culturalismo, apesar de não ter significado uma ruptura absoluta com as matrizes do conhecimento clássico, apontava para outras possibilidades do olhar e o fazia porque:

O trabalho de campo [emergente, porém, não consolidado] redimensiona o conhecimento científico, na medida em que exige uma rigorosa e sistemática apreensão de uma dada sociedade ou grupo em seus múltiplos aspectos, formais, institucionais, concretos, tal como se encontram relacionados entre si e de acordo com a representação que deles é feita. A cultura se torna, assim, central para a compreensão das práticas humanas, vistas como práticas significantes que distinguem o homem da natureza, $\mathrm{o}$ homem do animal e que fundam diferentes sistemas de interpretação da vida. (Gusmão, 1997, p. 21).

A cultura como universo simbólico será, então, da maior importância na compreensão da realidade social humana. $\mathrm{O}$ significado desse imenso passo na compreensão da diversidade sociocultural dos diferentes povos na face da terra não pode ser negado; porém, sua erupção no cenário científico e no senso comum de seu tempo não significou uma mudança efetiva nas relações concretas entre sociedades e culturas.

O culturalismo americano terá, como parceiro de um pensamento em mudança, o funcionalismo de origem inglesa, ainda no início do século XX e data- 
do entre os anos de 1920/1930. Centrado na concepção de função e de sistema, o funcionalismo compreende a sociedade de uma forma integrada, em que o todo resulta de partes interligadas, ao mesmo tempo em que as partes contêm em si o todo. Os procedimentos de análise do social podem então, eleger a parte e, por dedução, explicar a totalidade da vida social.

\begin{abstract}
Nesse processo o antropólogo é aquele que faz a "teoria nativa" da sociedade que estuda, ou seja, que busca explicá-la em seus próprios termos. Isso exige desde a compreensão da especificidade de cada cultura, já posta pelo culturalismo, como também a compreensão das partes que compóe uma dada cultura em termos de um todo integrado de que fala o funcionalismo. (Gusmão, 1999, p. 21)
\end{abstract}

Para essa corrente teórica, as necessidades de um grupo ou sociedade, bem como as respostas que estes dão a tais necessidades, decorrem da cultura. Será a cultura o elemento básico que possibilitará a originalidade e a especificidade de um grupo ou sociedade diante de outros grupos e sociedades. Contudo, nessa abordagem, os conceitos que prevalecem são os de sociedade e estrutura. A noção de cultura será entendida como um sistema de elementos interdependentes, que não podem ser compreendidos em separado. Importante, diz Cuche (1999, p. 71), "não é que tal traço (cultural) esteja presente aqui ou lá, mas que ele exerça, na totalidade de uma dada cultura, uma função precisa”. A função ou as funções a que se destina: suprir necessidades individuais e coletivas através de instituições sociais que ordenam e organizam a sociedade; entre estas, a escola.

Assim, a corrente americana com Boas e a corrente britânica com Malinowski, ainda que vissem a noção de cultura desde um ponto diverso, comungavam com o que iria, em definitivo, garantir à antropologia sua condição de ciência: o trabalho de campo. "Com eles, o trabalho de campo se torna a própria fonte de pesquisa e a condição modular da antropologia como ciência da alteridade que, segundo Laplantine, se dedica aos estudos das lógicas particulares de cada cultura." (Gusmão, 1997, p. 20).

Nesse quadro geral, o funcionalismo terá presença forte e significativa no modo de pensar a educação e a escola na primeira metade do século XX, mas a corrente culturalista americana será a que terá maiores preocupaçôes com a educação. Ruth Benedict e Margareth Mead dedicaram-se aos estudos do campo educativo e da diversidade das culturas a partir de diferentes ângulos. M. Herskovits, R. Redfield e C. Kluckholn buscavam a relativização dos "saberes e as conexões entre saberes diversos [que] só se fizeram possíveis em razão das experiências vividas e da integração no mundo e na cultura de cada um" 
(Gusmão, 1997, p. 20) e fizeram-se pioneiros ao colocar em pauta a educação multicultural, já nos anos de 1940/1950.

Contudo, apesar dos avanços representados pelas correntes americana e inglesa nas formas de pensar a diversidade humana, mesmo no campo da educação multicultural que emergia, nenhum deles questionou a natureza da intervenção das sociedades coloniais sobre outros povos, e pouco ou nada se questionou sobre a intervenção do antropólogo nas sociedades estudadas por eles. Isso não significa, porém, a inexistência de um movimento de luta das sociedades coloniais a desafiar o conhecimento estabelecido e as práticas coloniais que negam a heterogeneidade social e histórica dos diferentes povos. Do mesmo modo, um processo ainda em consolidação, em razão do trabalho de campo que marcou o funcionalismo (Malinowski), impôs a reflexão sobre o papel do antropólogo e da antropologia perante as sociedades e os sujeitos que eles estudam, colocando em pauta a necessidade crescente de relativizar o próprio conhecimento. Como parâmetro do pensamento de toda essa época, Cuche (1999, p. 46) considera a produção de Boas e afirma que

No fim de sua vida [1942], Boas insistia em outro aspecto do relativismo cultural. Um aspecto que poderia talvez ser um princípio ético que afirma a dignidade de cada cultura e exalta o respeito e a tolerância em relação a culturas diferentes. Na medida em que cada cultura exprime um modo único de ser do homem, ela tem o direito à estima e à proteção, se estiver ameaçada.

Não por acaso, um longo percurso levaria a que, ao final dos anos 1980/90, fosse esse o discurso a emergir em torno da questão das diferenças e dos direitos de grupos e sociedades à sua especificidade, um discurso avançado, porém não inteiramente novo. $\mathrm{O}$ que entra em questão é que, aparentemente diferente nos dias atuais, porque "respaldado em outros quadros teóricos", o problema da "retomada do culturalismo", como diz Consorte (1997), parece desafiar os estudiosos da diversidade social humana e, em particular, o campo da educação e de sua principal agência, a escola ${ }^{7}$.

De lá para cá, entre os anos de 1920 e 1930, sob inspiração do modelo funcionalista, a Antropologia da Educação tomou forma e ganhou presença e força no interior dos sistemas coloniais ainda vigentes, como uma "ciência de serviço" ou ciência aplicada. Seu percurso, como tal, abrangerá um largo período, dos anos de 1920 até 1950/60, quando as teorias de desenvolvimento assumiram a então chamada cultura popular ou tradicional como empecilho à

7. E o fez, contudo, tendo por referência não o campo das Ciências Sociais, ao qual a antropologia se vincula como ciência, mas o campo emergente dos estudos culturais entre 1980/1990, como se verá à frente. 
modernização e, necessitadas de mudança e transformação, tais teorias fariam da escola um instrumento do desenvolvimento; fariam dessa agência e de seus agentes os componentes fundamentais de uma ordem em mudança. A cultura tradicional seria, então, negada em seus termos para que se instaurasse uma cultura tida por significativa, posto que comungava com os ideais e os objetivos de uma ordem em mudança. $\mathrm{O}$ que não se questionava era o sentido da mudança, quase sempre forjado desde cima e em razão dos objetivos da sociedade (e do Estado), que buscavam pelo progresso e pela modernização, muitas vezes pensados numa concepção urbana de cultura e sociedade.

Nesse contexto, operou como um instrumento fundamental dos processos de mudanças das realidades ditas atrasadas a concepção da instituição escolar moderna. Organizada em torno de um sistema de ensino, a escola funcionava como um todo integrado pelas partes que a constituíam - administração, funcionários, pais, alunos entre outros, um todo orgânico e sistêmico —, tal como postulava a teoria funcionalista, da qual se resgatou inclusa a noção de comunidade ${ }^{8}$.

Os estudos de comunidade constituem a outra ponta da perspectiva antropológica que hoje parece retornar, sem uma efetiva consciência do fato, nas pesquisas educacionais deste fim de século. A proposta desses estudos conduz os pesquisadores a verem, no âmbito de pequenos grupos, a reprodução da sociedade, elegendo no campo da pesquisa o particular, como objeto de conhecimento, e não a generalização. A cultura vista nela mesma, no interior do grupo e a ele referida, contexto em si mesmo tornam-se expressão maior dessa perspectiva de análise, desse fazer científico. (Gusmão, 1997, p. 21)

Consorte (1997), em artigo sobre o culturalismo, mostra que este penetrou no Brasil em torno de 1930, para subsidiar o debate de nossa formação como povo e, posteriormente, já nos anos de 1950, atuou na forma de estudos de comunidade em razão do processo de modernização da sociedade brasileira. A autora fala, ainda, que "os pesquisadores [americanos e brasileiros], agiram em relação às suas comunidades como se elas fossem comunidades isoladas, fechadas sobre si mesmas, preocupando-se pouco em situá-las no contexto maior a que pertenciam." (1997, p.33). Como pesquisadora encarregada de avaliar, nesses estudos, o "esclarecimento dos problemas da educação", Consorte irá concluir que a escola não foi objeto de preocupação sistemática por parte desses estudos, perdendo-se a oportunidade de fazer a critica à "proposta homogeneizadora da escola, indiferente a latitudes e longitudes neste vasto

8. A respeito do conceito de comunidade e sua presença nos PCN, ver Teixeira (2003, p. 47-82). 
território nacional" (1997, p.33). Revela, assim, um limite dos estudos de comunidade e o fato de que as perspectivas culturalista e funcionalista não dão conta de que "'as relaçôes culturais estão submersas em relações de poder' (Carvalho, 1989, p.21) e, como tais, dizem respeito a realidades mais amplas, estruturadas em torno de relações de classe e baseadas em mecanismos de desigualdade e dominação." (Gusmão, 1997, p.22).

Assim, de meados de 1950 a meados de 1960, abriram-se dois campos. Alguns estudiosos, a partir da antropologia da educação, ainda que comprometida e não independente, seguiriam um caminho diverso daquele pretendido pelos modelos autoritários de desenvolvimento presentes no culturalismo e no funcionalismo. Comprometidos com a cultura tradicional e popular como veículo de conscientização e responsabilidade social, esses antropólogos buscavam recuperar da escola seu papel de "veículo de educação popular e permanente, isto é, um instrumento do verdadeiro desenvolvimento" (Fonseca, 1983, p. 4). O auge da chamada educação popular dar-se-ia inspirado pelos movimentos sociais dos anos de 1960/70. Não por acaso, será nesse mesmo período que os debates em torno da cultura popular e de massa, no confronto com as culturas de elite, darão o impulso necessário à emergência dos estudos culturais em duas de suas principais tendências: os estudos culturais ingleses ou Escola de Birminghan e os estudos culturais norte-americanos, nomeadamente no campo da literatura e das artes.

No Brasil, os ecos do movimento de resgate da cultura popular através da educação e da escola terão em Carlos R. Brandão uma referência. Os estudos da antropologia e da educação popular farão da pesquisa participante "uma modalidade nova de conhecimento coletivo de mundo e das condiçôes de vida de pessoas, grupos e classes populares" (Brandão, 1984, p. 9) e, através de estudos dessa ordem, dentre outros, instaura-se a prática política de compromisso popular. Nessa prática, diz Brandão, "a realidade social não é uma coisa dada e acabada, e que o pesquisador não pode ser um observador imparcial situado fora da situação que analisa” (Brandão, 1984, p. 23). Tal afirmação não acontece por acaso.

Em meados dos anos de 1950 e 1970 estava em movimento uma discussão crítica ao fazer da ciência e a sua pretensa neutralidade, defendida pelo conhecimento clássico que separa as atividades do campo científico realizada nas universidades e nas instituiçôes, das atividades e açôes sociais do campo político, onde atuam cidadãos comuns. $\mathrm{O}$ princípio pressupunha a não-contaminação do conhecimento pelo social e, como tal, separava a prática política da prática científica. Contudo, as intensas transformaçôes dos anos anteriores a 1950/1960 não permitiam mais um fazer científico distanciado da prática e dos sujeitos que ela estuda, com a ciência e o cientista protegidos numa redoma 
de cristal. Nesse contexto, a ciência começou a rever suas práticas sob pressão dos movimentos sociais emergentes.

O fazer da antropologia e do antropólogo não foram indiferentes ao movimento. A própria natureza do trabalho do antropólogo, segundo Fonseca (1999), muito antes disso, ainda no início do século XX, conduziu-o a ter que se defrontar com o mundo do outro e seu universo e o fez para descobrir-se a si mesmo e ao seu próprio mundo. $\mathrm{O}$ contato face a face desvelou uma realidade em que o objeto de estudo se fazia sujeito, não sendo este um mero informante, como no passado, e o antropólogo, um controlador de situações e variáveis em campo. O estranhamento de ambas as partes seria o componente fundamental da investigação antropológica e das possibilidades de descoberta de algo inteiramente novo, forjado no contato, na interação e na comunicação entre pesquisador e pesquisado. Aqui começava a ser redimensionado o sentido ou os muitos sentidos da noção de cultura como fato relacional, e não relativa, que diz respeito ao contexto concreto das relações sociais em movimento e cuja base é dada por processos históricos do passado, mas, sobretudo, do presente. Nesse sentido, a antropologia que emergiu nos anos de 1950/1970, envolvia uma nova concepção de cultura, não alheia ao contexto de mudança das sociedades em contato, e terá seu nexo num campo de forças e de poder que começava a ser reconhecido, em sua existência, como de contradição e de conflito. A ciência antropológica irá buscar, então, em novas correntes teóricas - o estruturalismo e o marxismo - as possibilidades de uma reflexão mais crítica e compreensiva da realidade social, capaz de superar as abordagens particularistas de cultura.

O estruturalismo será um reflexo desse novo tempo e teve por marco principal os anos de 1950 e 1960 . A preocupação dessa teoria estará posta na descoberta de outras racionalidades e representaçóes, na tentativa de superar a desqualificação do diferente. Para tal, o estruturalismo repensou a dinâmica da ação humana, suas manifestações sociais e alteridades, agora de modo mais pertinente, porém não era ainda "uma crítica real da desigualdade sócio-cultural que cerca a tão decantada diferença cultural, produto da dominação colonial e neo-colonial" (Carvalho, 1989, p. 21). Sistematizada a partir dos estudos de Levi-Strauss, a teoria estruturalista far-se-ia presente nos debates da corrente inglesa dos estudos culturais que discutirá a possibilidade de uma crítica cultural ou teoria cultural que se fazia como proposta acadêmica e movimento político. O debate cultural no interior do marxismo, este sim, capaz de formular a crítica social, levou a que os estudos culturais nascentes se confrontassem com as idéias de Louis Althusser, antropólogo de tendência marxista-estruturalista, que discutia as instituições sociais como aparelhos ideológicos do Estado, entre estas, a escola. A instituição escolar passou a ser questionada como instituição reprodutora da ordem social desigual e injusta (Althusser, 1998; 
Bourdieu; Passeron, 1975) e colocou-se em tela a noção de ideologia'. Não por acaso.

No quadro mais geral, na segunda metade do século XX, a África impôs ao mundo sua presença através das lutas por independência, confrontando-se com o colonialismo ainda em processo de sobrevida. Duas guerras mundiais haviam dilacerado as certezas do mundo ocidental e a questão da humanidade, reconhecidamente diversa, estava em debate. A diversidade sociocultural presente na sociedade moderna impunha como necessidade ser reconhecida e dimensionada dentro e fora da escola, vale dizer, no interior da sociedade e da cultura que lhe é própria. No entanto, esse processo de reconhecimento não poderia limitar-se à admissão das diferenças, tal como acontecia no culturalismo e no funcionalismo, sob pena de perder-se na superfície da realidade social e no jogo ideológico dos valores vigentes e operantes na compreensão de mundo que permeiam as relações sociais.

Nesse sentido, a ordem que se impôs ao mundo de então acusou a antropologia por seu passado de serviço ao colonialismo e suporte de expansão do capitalismo. Afirmava que a noção clássica de cultura não mais atendia às necessidades desse novo tempo. Diante do fato, a ciência antropológica reviu seus passos, reordenou seus princípios e se pôs diante da tarefa de fazer uma ciência engajada a serviço das populações dominadas que sempre foram objeto de seu olhar. Reviu, também, as potencialidades de seu conceito central, a cultura. Corriam os anos de 1960/1970. O marxismo somou e dividiu o campo científico, a exigir da ciência, qualquer uma, uma postura de instrumento de outra política, mais engajada e comprometida. Questionou, também, o alcance do conceito de cultura, agora, diante de uma sociedade de classes. A percepção crescente da cultura como campo de tensão e conflito permeava, então, não apenas o campo da teoria e da prática no fazer da ciência, mas também se fazia presente no debate em torno do fazer social e político.

\section{Antropologia, estudos culturais e educação}

Ao cruzar a antropologia e a educação no campo da cultura, buscando compreender os caminhos de apreensão do mundo social pelos paradigmas vigentes entre dois séculos - século XIX e século XX — evidenciou-se que a história da ciência antropológica a conduziu em direção à afirmação da diversidade sociocultural e do relativismo. $\mathrm{O}$ fato a colocou e a coloca em condição poten-

9. A escola de Birminghan postulava como necessário saber se a cultura permitiria apenas a reprodução do social, tal como se apresentava no discurso de Althusser, porque hegemônica, ou se a partir dela, cultura, seria possível suplantar a hegemonia colocada pela ideologia dominante e permitir uma mudança radical da sociedade. 
cial de interlocutora no interior do século XXI, em razão de sua experiência e de sua história. Por sua vez, a história da educação, por meio de suas práticas educativas - campo da pedagogia - conduziu-a na direção da afirmação permanente da homogeneidade colocada ainda no século XIX e centrada na busca por universais humanos, como valor e como ideologia. Como tal, a educação foi desafiada a responder às diversidades sociais humanas que se impunham $\mathrm{e}$ se impóem como realidade e como direito no alvorecer do século XXI.

Nesse movimento, a antropologia construiu seu caminhar, definindo um método próprio de fazer ciência, construindo seu objeto a partir de uma forma particular de fazer perguntas, construir estratégias, para penetrar no universo do outro, seu sujeito, podendo com ele investigar e buscar explicaçôes para os fatos da vida humana. A perspectiva singular com que olha a realidade e opera o conhecimento, ainda hoje, resulta das teorias que emergiram ao longo da modernidade e que permitiram a adequação de seu objeto — das chamadas sociedades simples às sociedades complexas - e de si mesma como ciência. $\mathrm{O}$ contexto histórico que toma por pano de fundo o Ocidente e a colonização, o contato e o confronto com outros povos e outras culturas, visando suprimir toda e qualquer alteridade pela imposição de um modelo de vida, torna-se o elemento crítico fundamental de uma revisão de si mesma como ciência da diversidade. Ao mesmo tempo, no pano de fundo da história, a educação e sua prática, ainda em busca de homogeneização e dos universais humanos, determinaram-se como um efetivo processo de ensino centrado em modelos pedagógico e cultural diversos, porém que não venceram a contento a natureza etnocêntrica e homogênea presente na instituição escolar.

Portanto, não será por acaso que os anos de 1950/1960 serão um divisor de águas da realidade histórica contemporânea e, também, um momento crucial de divisão na produção do conhecimento. $\mathrm{O}$ campo científico encontrava-se cindido em dois momentos: o passado com suas Teorias de Equilíbrio ${ }^{10}$ e o presente com suas Teorias do Conflito $^{11}$. Entre um e outro, a modernidade e sua aparente superação - a pós-modernidade - encontrava-se em gestação.

Uma aproximação esquemática do movimento que vai do pensamento clássico dos séculos XVIII e XIX até o século XXI revela a presença da concepção positivista de sociedade (Teorias do Equilibrio) que, nesse largo tempo, apenas

10. As teorias do equilíbrio, nomeadamente o evolucionismo e o funcionalismo, encontram-se atravessadas por outras correntes, tais como o difusionismo, o culturalismo ou a história cultural e têm por característica a manutenção do status quo da sociedade. Visam sua manutenção e reprodução de forma harmoniosa.

1।. As teorias do conflito, tais como o estruturalismo, o marxismo, o interpretativismo e outras indicam a noção de conflito como a base dos processos de transformação social da sociedade, em particular, as sociedades de classes. 
alterou o próprio discurso para mostrar-se em consonância com as mudanças, mas que não chegou a mudar fundamentalmente sua forma e conteúdo. $\mathrm{O}$ individualismo metodológico que tomou o social como centro do olhar e que acompanhou a produção de conhecimento nesse largo período colocou no indivíduo a tônica da realidade social. O fato será denunciado pelas diferentes teorias no nascer do século $\mathrm{XX}$, mas estas não avançaram mais que isso na emergência das humanidades e no fortalecimento da noção de cultura que consolidou as chamadas ciências humanas via as correntes culturalista, funcionalista, estruturalista e parte do marxismo. Com isso, o holismo metodológico que assume a sociedade como centro do olhar introduziu um tratamento mais compreensivo e interpretativo da sociedade presente na evolução do pensamento científico de então; contudo, não superou os limites de que se acusa a modernidade. A razão está em que tanto o individualismo como o holismo consideram o indivíduo e a sociedade desde um lugar que é o olhar dominante - naquele momento, a sociedade colonial e européia —; olhavam de cima para baixo como parte dos processos de submissão e dominação que imperavam no tecido histórico, em sua centralidade e em seu etnocentrismo.

As vozes dissonantes serão vozes de protesto, de denúncia, mas não de superação. O campo de mediação entre os extremos que representavam começaria a ser construído nos anos de 1950/1960. Nessa época, as teorias emergentes (Teorias do Conflito) começavam a desafiar a concepção de mundo através dos movimentos sociais, das transformações históricas e das conseqüências das guerras mundiais das décadas anteriores e das lutas por libertação e guerras civis em África, demandando a urgência de outro modo de pensar a humanidade. $\mathrm{O}$ interacionismo simbólico emergente impunha a necessidade de relações face a face e instaurava o debate em torno do pesquisador como sujeito político, da pesquisa como realidade engajada e momento crucial de permanência ou de superação da produção de conhecimento por vias disciplinares constituídas na modernidade. Não por acaso, portanto, a chamada crise dos paradigmas expressou-se significativamente ao final do século XX, colocando em debate as teorias interpretativas e as possibilidades da chamada pós-modernidade.

As novas concepções de ciência diziam respeito a um espaço de fronteira, discutido hoje, em termos da compreensão desse espaço como de interação, centrado no contato e na comunicação entre sujeitos. Um espaço que, por ser dinâmico e de fluxo contínuo, faz emergir formas específicas de percepção, cognição e representação. Um espaço, desde sempre, familiar à antropologia, cuja prática, o trabalho de campo, tornou necessário as relações face a face com outros sujeitos, outras culturas e outras sociedades. Tornou necessária a compreensão a respeito do outro e de sua vida, do outro e de suas visões de mundo, como não alheias ao próprio mundo do antropólogo, a sua visão de mundo e à 
ciência que pratica. A reflexividade descoberta no trabalho de campo e um dos suportes da ciência antropológica colocou o desafio da relativização e da comparação das relaçôes concretas entre os homens, entre o pesquisador e o pesquisado, entre a ciência que pratica e a ciência que se encontra legitimada como tal. A compreensão do contexto histórico e político das relaçôes entre sujeitos tornava-se obrigatória e, para tanto, a antropologia ampliou seu conceito-chave - a cultura - para além da condição de símbolo e significado, para apreendê-la como estrutura de sentido e de comunicação, entendendo-a como mediação num contexto relacional, marcado por embates de um campo de força e de poder. Assim, entre as ciências descritivas e classificatórias do pensamento clássico e o novo momento, a exigência de teorias mais compreensivas e críticas se impunha com força.

Para Lovisolo (1984, p. 57), tal demanda imposta pela natureza das sociedades ditas complexas habilitou e habilita a antropologia na interpretação do tempo presente. As características metodológicas construídas no passado e centradas na descrição etnográfica uniram-se a um esforço etnológico de explicação das sociedades ditas simples, desde o primeiro momento do contato destas com a chamada civilização. Por essa razão, a antropologia realizou, em sua trajetória, um "grande esforço etnográfico [que] foi acompanhado de um trabalho etnológico de porte semelhante", vale dizer, uniu a descrição de grupos e sociedades a um trabalho analítico (explicativo/interpretativo) significativo na compreensão desses grupos e sociedades. Mais do que isso, pode-se dizer que hoje,

a aceitação da antropologia pela sociedade complexa convive com a emergência da representação de sua diversidade [...] que começa a se opor/aliar a uma imagem de uma sociedade formada por grupos ou identidades coletivas (étnicos, religiosos, culturais, etc.) interagindo de formas diversas (Lovisolo, 1984, p. 59).

Nesse sentido, diz Lovisolo, o fato de as sociedades pensadas pela antropologia nunca terem sido universais fez com que essa ciência, desde sempre, tivesse por objeto "a diversidade, a diferença entre sociedades, suas singularidades e as formas de construção dessas identidades" (1984, p. 59). É exatamente sobre esses mesmos pontos que as realidades complexas exigem a renovação do arcabouço teórico moderno, e é aqui que a antropologia, por seu método e por suas categorias de análise, se faz fundamental.

Lovisolo defende a existência de uma

antropologia interpretativa vinculada ao lado ativo da vida humana e toma como objeto de interpretação a intersubjetividade, [e que] foi a que penetrou e está sendo aceita na sociedade complexa no contexto geral da revalorização da 
subjetividade; a antropologia que pensa o homem como constituído e constituindo o tecido de significações que são seus meios, suas condições e seus fins. Diria que no campo educacional ela tem um papel relevante a desempenhar (1984, p. 67).

Contudo, segundo o autor, "o grande paradoxo é que no reconhecimento da diferença, no 'respeito' das singularidades éticas, raciais, culturais, etc., conservadores e revolucionários [na educação, tal como em outros campos] encontram-se trilhando caminhos diversos" (Lovisolo, 1984, p. 61). Em questão, uma concepção positivista de sociedade construída como parte das visões clássicas do passado e a necessidade de construção de uma concepção compreensiva e interpretativa de mundo, que chega até os dias de hoje e nos desafia.

Em todo o contexto descrito, percebe-se que os passos da antropologia e da educação como prática (a pedagogia) se iniciaram de um mesmo patamar e com uma mesma natureza, mas começaram a distanciar-se e a fazerem-se divergentes nessa mesma caminhada. A antropologia seguiu os desafios de cada momento histórico, preocupada em explicar a diversidade social humana a partir das singularidades e particularidades que revestem diferentes grupos e sociedades. Entre um século e outro, privilegiou o campo das diferenças e caminhou em sentido do reconhecimento das diversidades socioculturais de seu tempo. Atrelada aos universais humanos, a educação chegou ao final do século XX colocando, para a pedagogia, o desafio de ter que admitir as diferenças e de estabelecer um modo de dialogar com elas, mas que ainda não encontrou sua plena realização.

$\mathrm{Na}$ necessidade de superar os limites do momento anterior e na ânsia de superar o denuncismo daquele momento para transformá-lo efetivamente numa ciência mais engajada e mais prática, o campo científico como um todo elegeu o interacionismo como fundamental na compreensão do outro. Ainda que se tratasse, agora, de colocar face a face sociedades, culturas e sujeitos diversos, postulando o conhecimento mútuo em condições de igualdade e eqüidade, sem reproduzir as relaçôes assimétricas do passado e da história ocidental, tal não aconteceu sem contradições e conflitos. Reconhece-se a condição de ação de homens concretos, de sua interação e comunicação, pensada em Marx como práxis social, mas o que o interacionismo buscava era o caminho da mediação das relações entre os homens, que não reificasse o homem ou a sociedade, mas que os colocasse em diálogo. Um caminho intermediário no qual a cultura devia ser vista não tão-somente como universo simbólico, contexto de símbolos e significados, como no passado, mas que fosse vista, também, como comunicação e mediação no interior de um campo de relações. O fato é que, desde sempre, as sociedades humanas estão em contato e em relação e, aqui, a antropologia armou-se de sua história e memória para responder aos desafios dos 
problemas contemporâneos relativos à diversidade social, buscando compreendêla em contexto. Um contexto simbólico, mas, sobretudo, um contexto de relações historicamente determinadas e, como tal, um campo político e de poder. Nesse sentido, como diz Gusmão (1999, p. 46):

A cultura e seu movimento incorpora ainda uma outra dimensão que é seu caráter de mediação, ou seja, aquilo que faz com que as condiçōes objetivas de vida sejam expressas pelos sujeitos sociais, não pelo que de fato são e representam, mas pela forma pela qual o real é significado, percebido e interpretado. Cabe aos indivíduos e grupos, perceber, significar e interpretar a si mesmos em relação ao que vivem e experimentam e que, impregnam a textura social do cotidiano, enquanto imagem, rotina e ruptura, enquanto universo significante que é parte da vida vivida, pensada, sentida e concebida.

Aqui as potencialidades da antropologia, ciência gestada na modernidade, impunham-se de maneira particular e a colocavam como precursora do que se apresentaria como exigência ao final do século XX. Na sua origem, a antropologia privilegiou a alienidade, porém, em sua caminhada, ainda na primeira metade do século XX, descobriu e elegeu as relaçōes face a face no trabalho de campo como seu modo de fazer ciência. A etnografia, como seu método central, tem na reflexividade um caminho de dupla mão, de ida e volta a dois universos simbólicos - o do pesquisador e seu mundo e o do pesquisado e seu mundo. Pode-se dizer que, na modernidade, a antropologia e o fazer do antropólogo são já de interação, partilha e comunicação. Assim, a comparação e a relativização constituem-se como pilares fundamentais de seu modo de fazer ciência ${ }^{12}$. Nesse fazer, pesquisador e pesquisado constituem-se como sujeitos em relação. A subjetividade do pesquisador e do pesquisado, que primeiramente a desafia como ciência, torna-se componente básico e essencial da análise antropológica. Torna-se um paradigma de conhecimento. Com isso, a antropologia, entre as humanidades, segue um caminho de constituição em que sua natureza científica se define não pelo objeto, mas pelo modo de fazer ciência, ou seja, seu método e o que vem com ele, suas categorias de análise.

Para sintetizar esse debate, conclui-se que, na antropologia como ciência, a passividade do sujeito - tido como objeto - e da cultura, como somente descrição, pode ser vista como parte de uma fábula que se conta na luta disciplinar do final do século XX, por não se situar de modo mais crítico e temporalmente a história dessa ciência.

12. Ver, a respeito desse debate, o excelente texto de Claudia Fonseca (1999, p. 58-78). 
Da antropologia e dos estudos culturais: a questão da educação e da escola

A escola construída sobre a afirmação da igualdade e enfatizando a base cultural comum a todos ${ }^{13}$, diz Vera Candau (2002), enfrenta o desafio de ter que articular igualdade e diferença, a base cultural comum e expressôes da pluralidade social e cultural, colocando em jogo, no processo educativo, as relaçôes entre o multicultural e a educação; o cotidiano escolar e a formação de professores, em razão de como se expressam a diversidade, a intolerância e o tratamento desigual do diferente. Contudo, com base nisso tudo, que são fatos reais e concretos (o multicultural), no final do século XX, o relativismo cultural dos anos de 1930 é revisitado nos anos de 1990 em diferentes práticas e estudos pedagógicos. Isso ocorre em razão da não-reflexão crítica desse movimento que tipificou a antropologia daquele momento e, em particular, a antropologia da educação. Em questão: como articular, no campo educacional ${ }^{14}$, valores universais (próprios das sociedades verdadeiramente democráticas) e as especificidades culturais, ou seja, o singular e o específico de cada grupo, sociedade e cultura?

Não sem razão, portanto, o multiculturalismo, como campo teórico de explicação dessa realidade e base de construção de uma prática e intervenção emergiu no campo educacional após os anos de 1960 e firmou-se como perspectiva nos anos de 1990. Emergiu, porém, centrado na prática mais que na teoria e como tal se tornou elemento fundamental, não do campo educacional, mas da ação educativa. ${ }^{15} \mathrm{O}$ multiculturalismo dirá, então, da necessidade do reconhecimento das diferenças no interior de uma visão política comum e democrática, capaz de garantir as liberdades individuais e particulares (Valente, 1993, p. 11). O modo como o faz, porém, revela muito de sua complexidade e contradição.

13. Cabe observar que a cultura, como fato comum presente em toda e qualquer sociedade humana, não pressupõe a existência de uma "base cultural comum" a todos os homens, tal como pressuposto pela escola como instituição.

14. Campo Educacional é de ordem mais ampla e crítica, pois busca uma visão compreensiva da realidade social, mais interpretativa, ordenada pelo campo político e pelas relações de poder. Nele se discute o ser e o dever ser de sujeitos sociais concretos e seus múltiplos significados. Tem por paradigma a noção de conflito. Considera a dinamicidade da produção e da reprodução do mundo social. O ser social é aqui participante ativo do social e sujeito de conhecimento.

15. Ação Educativa ou educacional é de ordem prática e mais prescritiva. Estabelece diagnóstico e prescreve a ação de intervenção sobre uma dada situação, com o intuito de dar solução ao que é tido como "problema". Objetiva, assim, por meio da socialização, interiorizar sentimentos, hábitos, valores inerentes à ordem social. O ser social é, aqui, sujeito passivo das relações de ensino. 
No campo antropológico o problema coloca-se, segundo Valente, de modo a garantir que é possível inserir microrrealidades em contextos mais amplos e que a realidade do campo educacional não pode ser reduzida à sala de aula ou à escola em si mesma, como freqüentemente acontece nos estudos relativos à educação. Não se pode, também, segundo Valente, higienizar o espaço da escola, vê-lo como neutro, higienizado de seus males em nome de um "humanismo inútil” porque pragmático e utópico, ou ainda, geral, abstrato e ideológico. Afirma a autora:

O que pode e deve fazer a escola para promover sua própria transformação é devolver ao discurso escolar aquilo que é hoje ocultado: o uso social que é feito dos conhecimentos que ela transmite. (Valente, 1993, p.13)

A questão está em que a chamada educação multicultural desconhece os caminhos já trilhados pela antropologia e elege seus estudos e propósitos em torno da educação e da cultura, por meio do que é designado, principalmente nos EUA e com sucesso na educação brasileira, de estudos culturais.

Terence Turner, citado por Kuper (2002), afirma que os cultural studies surgidos nos EUA influenciaram diretamente a ascensão do multiculturalismo. Para o multiculturalismo, a noção de cultura resulta de concepçôes presentes nas belas artes, na literatura, nos conhecimentos, nas artes negras, na cultura popular. Segundo Adan Kuper (2002, p. 291), são campos que consideram diferentes formas de culturas valorizadas como distintas, porém, sempre em relação a uma cultura oficial - a alta cultura - na contraface de uma cultura de massas que, por falsas, impedem a emergência da consciência e da luta por direitos. Por essa razão, diz Kuper, Stefan Collini critica os estudos culturais, afirmando que "o dever dos que estão engajados nos estudos culturais é 'subverter', 'desmascarar', 'contestar', 'des-legitimar', 'intervir', 'combater’”, próprio de um ativismo político e denuncista. Contudo, tal dever não parte de uma reflexão sistemática e crítica que possibilite não apenas reconhecer o outro, mas conhecer o outro para que o reconhecimento se faça possível para além das identidades singulares.

Os estudos culturais envolvem a questão do poder dominante e fomenta políticas culturais mediante o que considera uma nova abordagem da cultura ou da teoria cultural (campo da literatura), agora não antropológica, tida como apolítica, mas numa concepção mais política e engajada, própria desse novo campo. Dessa forma, os estudos culturais propunham-se a romper com a tradição antropológica, visando apresentar uma proposta acadêmica de crítica cultural que fosse também, e a um só tempo, um movimento político. Tais estudos elegem a prática mais que a teoria e, se criticam o tempo de antes como 
sendo eminentemente teórico e pouco prático, assumem agora seu oposto extremo - a prática engajada e militante acima de qualquer coisa. Foi essa forma de olhar que emergiu nos EUA dos anos de 1960 e cresceu nos anos posteriores, em simbiose com os movimentos sociais orientados por diferentes grupos, primeiro os negros americanos e sua confrontação com o Estado americano; depois, outras minorias como o feminismo, o homosexualismo e outros.

A particularidade que define a identidade desses grupos ganhou visibilidade e expressão, dizia deles em suas singularidades, mas pouco permitiu com relação à possibilidade de compreensão de uma ordem mais geral, em que esses mesmos grupos se encontravam inseridos. As relações que aí se manifestaram apontavam para a interioridade de cada grupo a reivindicar uma identidade própria e alvo de direitos perante o Estado, que tendia e tende a homogeneizar a realidade social e que dizem de sua relação com o Estado-Nação como marcadamente de domínio e exclusão. O que não se diz é da natureza mesma dessas relações como cultura e como ideologia. No campo da militância tudo é uma só e mesma coisa. Aqui operam reducionismos diversos que implicam dizer que toda cultura serve ao poder e que é ou deve ser contestada, sem distingui-la do campo ideológico propriamente dito. Por sua vez, a concepção de cultura restrita ao campo das artes, das mídias e ao sistema educacional reduz a concepção de cultura à condição de produto cultural, sem lhe reconhecer a condição de processo cultural, dinâmico e em permanente fluxo, como diz a antropologia.

Como afirma Kuper (2002), para muitos, o multiculturalismo que aí emerge, embora apresente questôes pertinentes dos desafios de nosso tempo, não é um movimento coeso, como por vezes se pretende: suas muitas escolas e tendências (como a inglesa, a francesa, a australiana, a canadense) exigem muitos debates e questionamentos. Entre estas está o que os antropólogos defendem: toda cultura é multicultural e a diversidade humana é mais função das relações que unem os grupos do que função de seu isolamento, como lembra Levi-Strauss. O fato exige olhar para as relações entre os homens, e não para as diferenças de que são portadores ${ }^{16}$. Volta-se, portanto, à descoberta central da antropologia sobre as relações de alteridade que constroem a história do mundo ocidental e moderno.

Para Kuper (2002, p. 309), "as teorias modernas [vale dizer dos anos de 1980/1990] reciclam as anteriores e se prestam a propósitos políticos seme-

16. Para Renato Ortiz (2000, p. I 65-166), a diferença remete a alguma coisa outra, que é produzida socialmente e porta um sentido simbólico e histórico, mas não é equivalente à noção de diversidade, principalmente diversidade cultural, que conduz a pensar situações concretas e mergulhadas em campos de interesse e de conflitos sociais, tais como os que emergem no interior do capitalismo e da globalização. 
lhantes - confrontam objeções, são reformuladas de modo ambíguo e fraco". O que dizem não é nada de extraordinário, ainda que algumas luzes sejam lançadas por essas teorias. Para o autor, é preciso separar os vários processos que agrupamos indistintamente sob o rótulo de cultura (grifo meu) e "olharmos além do campo da cultura para outros processos se quisermos conhecer a cultura de um grupo ou sociedade". Para ele, a teoria da cultura - estudos culturais - desvia a atenção do que temos em comum e que permitiria nos comunicarmos através das fronteiras nacionais, étnicas, religiosas e, assim, irmos além dela - cultura —, não permanecendo na diferença pela diferença, uma armadilha perigosa para as sociedades humanas.

A proposta do autor de ir além da cultura exige reconhecer outros processos sociais que desde a segunda metade do século XX têm gerado contextos tensionais decorrentes da diversidade social e desta como decorrência de processos estruturais de uma sociedade de classes e de sua complexidade. Vale dizer, na qual nem tudo é só cultura, mas é também ideologia. E, como tal, é preciso distinguir uma da outra para entender os nexos e os confrontos que se apresentam nas relaçóes entre os homens e suas sociedades, bem como entender a capacidade explicativa de cada uma dessas noções para não reduzir o olhar, culturalizando a política ou politizando a cultura ${ }^{17}$. Aqui, certamente, a noção de cultura em seu sentido antropológico deve ser resgatada para colocarse de modo complementar e acrescido no contexto político da modernidade. Sem isso, a questão da diversidade e o respeito às diferenças, ao ensejar experiências educativas na escola, correm o risco de tornar-se um discurso técnico, prescritivo e inócuo.

O debate importante e não resolvido por inteiro - o conceito de cultura e $o$ campo que o origina, a antropologia - é uma discussão que ora avança, ora se retrai. $\mathrm{O}$ fato exige apontar para a amplitude do conceito, para sua dimensão política e para seu alcance explicativo, para além da questão simbólica e, portanto, numa visão da ciência antropológica moderna e crítica.

Como se diz entre antropólogos, a antropologia nos EUA é hoje "Cultural Studies" e, como tal, difere de outras partes do mundo, onde persiste como Antropologia (s); posto que mesmo plural, não desconhece suas linhagens, nem sua história ${ }^{18}$. Por essa razão, praticar estudos culturais no Brasil ou mesmo na América Latina, como diz Renato Ortiz (2004), não é a mesma coisa que no caso americano. No Brasil e na América Latina, na concepção do autor, os estudos culturais encontram-se voltados às humanidades, como campos disci-

17. Ver, a respeito, o texto de Eunice Durhan (1984, p. 71-89).

18. Marisa G. S. Peirano, antropóloga da UNB, trata do tema em diversos artigos. Ver, da autora, o ensaio Antropologia no Brasil (alteridade contextualizada), publicado em Miceli (1999, p. 225-266). 
plinares, principalmente na comunicação e nas artes. Contudo, diz o autor, se os estudos culturais se configuram como uma área de conhecimento, a resposta pode ser positiva para o caso das universidades norte-americanas,

$$
\begin{aligned}
& \text { mas, negativa, ou no mínimo ambígua, quando nos voltamos } \\
& \text { para a América Latina. No que toca ao Brasil, parece-me que a } \\
& \text { penetração dos Estudos Culturais se faz pelas bordas, ou seja } \\
& \text { [...] na periferia do campo hierarquizado das ciências sociais. } \\
& \text { (Ortiz, 2004, p.121) }
\end{aligned}
$$

Ortiz afirma que os estudos culturais não existem no Brasil como área disciplinar, como é o caso dos EUA. Ainda que se pontuem interesses nesse campo, tais interesses, aqui, voltam-se ao que é produzido na Inglaterra via escola de Birminghan, enquanto, nos Estados Unidos, o interesse gira em torno de estudos literários, pós-modernidade e globalização. Entre nós, nos institutos e nos departamentos das ciências humanas, as tradicionais divisões de ensino e pesquisa persistem, de forma prevalecente, porém, numa convivência sem atritos com a nova tendência. Está em questão, nesse fato, a condição histórica diversa que reveste a América Latina, posto que, neste contexto, "a temática cultural, associada ao dilema da identidade nacional, foi uma preocupação permanente da intelectualidade. [...] A constituição da nação implicava uma reflexão diferenciada" (Ortiz, 2004, p. 124). Fundamental, diz ele, é que

O dilema da identidade nacional levou a intelectualidade latino-americana a compreender o universo cultural (cultura nacional, cultura popular, imperialismo e colonialismo cultural) como algo intrinsecamente vinculado às questōes políticas. Discutir "cultura" de uma certa forma era discutir política (p. 125).

Desse modo, o caso particular da América Latina comunga, por sua história, com parte da antropologia e com alguns antropólogos, como também com "grandes escritores sobre cultura [que] jamais duvidaram de que a cultura fosse uma questão política (Kuper, 2002, p. 290). Na verdade, diz Kuper ao citar Turner, com os estudos culturais "o debate da cultura voltou [grifo meu] a ter um caráter político (p.289). Contudo, estranhamente, através dos estudos culturais, principalmente após os anos de 1990, a noção de cultura se generalizou e se banalizou, tornando-se vazia de significado e alcance explicativo; ao mesmo tempo, o conceito de ideologia foi esquecido e banido das análises científicas e dos textos acadêmicos. Cabe, portanto, perguntar o que isso explica ou esconde a respeito de nossa realidade e da ciência que praticamos.

Ao perguntarmo-nos sobre as categorias de apreensão e explicação da realidade com a finalidade de lhes fazer a crítica e construir um conhecimento crítico de outra ordem, colocam-se em tela nossa historicidade particular e as 
possibilidades de diálogo e de confronto entre a antropologia e a educação, como ciência e como prática. Com isso, a natureza própria de cada campo e a história que as constitui entram em relação, complementaridade e conflito. $\mathrm{O}$ fato exige pensar a produção do conhecimento como teoria e prática que orientam processos de intervenção cuja característica central é ser, sempre, social e política, porém historicamente determinada, o que exige um mergulho no que é particular e específico de nossa realidade, para com ela dizer do que é geral e universal no campo teórico.

As críticas a uma dada antropologia do passado - clássica ou moderna da qual se diz que não serve ao novo momento representado pela crise dos paradigmas, ensejam a reação dos antropólogos e da antropologia para dizer de um lugar outro capaz de contribuir para as questôes desse novo tempo. $\mathrm{O}$ confronto disciplinar que se estabelece e origina espaços de constituição e institucionalização desse novo campo disciplinar, os estudos culturais, não pode ser simplesmente transposto a realidades outras, tais como a da América Latina ou a do Brasil. O equívoco do momento em que surge tal proposta, e válido para além desse espaço sócio-geográfico, é o de supor que ciência e política sejam fatos opostos entre si. Ranço herdado do positivismo do século XIX, que não reconhecia que o campo científico e disciplinar, além de não ser neutro, não se congelou no tempo, mas também se modificou para dar conta dos desafios de cada momento ao longo do século XX.

Como afirmam L'Estoile, Neiburg e Sygaud (2002), a bíblia acadêmica da primeira metade do século afirmava que as relações entre ciência e política envolviam dois contextos. No primeiro deles, os pesquisadores seriam capazes de distinguir as atividades que realizavam como cientistas nas universidades e nas instituições de pesquisa daquelas que realizavam como cidadãos no campo político. Opunha, assim, o público e o acadêmico, a pesquisa "pura" à pesquisa aplicada. Os dois mundos não se confluíam ou se comunicavam. O segundo contexto coloca a ciência a serviço da política, visando racionalizar e solucionar problemas sociais por meio da utilização do conhecimento científico ou da pesquisa engajada. Esta segunda opção vai além da academia, comunga com a realidade pública e militante e torna-se mais polissêmica. Contudo, ambas as posições são tipos ideais, pois, como se vê pela história do campo científico e em particular na história da antropologia na modernidade, não acontece tal como postulam uma e outra posição. A ambigüidade das relações entre ciência e política esbarra nas fontes de financiamento de que dependem tanto as pesquisas mais teóricas como as mais engajadas e intervencionistas, colocando em questão o fato de ser ou não uma ciência pura ou uma ciência aplicada.

É preciso que se olhe o contexto histórico e sua variabilidade no tempo e no espaço para que se possa definir autonomia, engajamento no conhecimento que 
produzimos. Como diz Steve Shapins, citado por L'Estoile, Neiburg e Sigaud (2002, p. 15): "a definição do que constitui a 'ciência"' e do que lhe é 'exterior' não pode ser tomada como dada: ela é uma construção que varia no tempo".

Como explicar, portanto, que tantos trabalhos no campo da educação brasileira assumam que a contribuição do multiculturalismo foi a de transferir "o terreno político de uma compreensão da diversidade cultural que esteve restrita, durante muito tempo, a campos especializados como o da antropologia"? (Souza, 2002, p.160).

Vale lembrar, como Montero e L'Estoile, Neiburg e Sygaud, citados no início deste trabalho, que a oposição ciência e política oculta a existência de relações da prática científica, a formação e o funcionamento dos estados nacionais. Conduz o olhar a focalizar os dilemas morais de determinados momentos da história que envolveu o fazer científico, desviando a atenção do papel do Estado na criação e na manutenção das instituições nas quais o conhecimento é produzido. Nesse sentido, os estudos culturais, ao fazer a crítica à antropologia e a sua noção de cultura, fazem-no para denunciar um dilema moral, o de reconhecer a diferença, mas apenas e tão-somente sob a égide do politicamente correto. Vale dizer, na sua superfície, e não em sua interioridade histórica marcada por avanços e limites, os quais não estão de todo esquecidos ou perdidos.

A partir do que dizem os autores acima, pode-se perguntar: alegar o passado da antropologia como moralmente comprometido com os dominantes e ser ela e seus conceitos acríticos, não seria um modo de buscar afirmar e legitimar um campo emergente - os estudos culturais? Esse campo que se institui não buscaria sua legitimação no interior de um mesmo espaço de saberes, através de discursos e práticas delimitadas que envolvem relaçôes de concorrência e de dependência com outros saberes e especialistas, eles próprios dependentes do Estado? Como pensar autonomia e engajamento da ciência que praticamos? Como contextualizar os discursos acadêmicos - da antropologia e dos estudos culturais - e os debates sobre políticas estatais, já que ambos, pelo menos em parte, desenvolvem-se num mesmo espaço social que obriga a não pressupor distinção entre esses universos?

A problemática da divisão de trabalho entre disciplinas serviu de combustível à emergência dos estudos culturais, determinando um espaço de lutas pelo monopólio da formulação e da aplicação das políticas que procuram se legitimar com base no conhecimento científico. Os estudos culturais, nascidos como uma antidisciplina e um movimento político, chegaram ao século XXI como mais um campo disciplinar. Mais um. O fato exorta-nos à necessidade de comparar as diferentes posiçôes, recolocando no contexto de um universo mais amplo o engajamento do antropólogo (ou de outros cientistas e seus campos) mediante uma leitura mais compreensiva e crítica em termos de similaridades e diferenças 
de dados episódios da história da antropologia (e das ciências da modernidade). É preciso compreender o que nos une e o que nos separa em termos da ciência antropológica e dos estudos culturais, pelo redimensionamento dos laços entre práticas acadêmicas e política; analisar o lugar variável da antropologia como ciência e como campo disciplinar de ensino e pesquisa, para entender o que se passa. Importa resgatar do interior da antropologia seu método (teoria e prática), que permite fazer das questôes práticas, questōes teóricas (e não seu universo), ou seja, que possibilita tomar a realidade como objeto de reflexão, sem substituir a reflexão local (pequenos grupos, sala de aula, escola) pela reflexão teórica. O que importa é o papel da reflexão como mais significativo e importante do que o ativismo que deve informar a reflexão teórica, mas nunca comandá-la.

Como cidadãos, antropólogos ou não, participamos todos dos problemas do País e também dos grupos minoritários que investigamos, mas cabe a nós perceber a grande agenda, as grandes questôes que nos levam a não permanecer no particular, no específico deste ou daquele grupo. $\mathrm{O}$ desafio que o positivismo não via e que as demais correntes teóricas sempre enfrentaram ainda permanece o mesmo em pleno século XXI: como ir do particular para o geral, objetivo de toda e qualquer ciência e sua prática. Aqui a antropologia, como ciência da modernidade, tem algo a dizer às nossas modernas e complexas sociedades do presente.

\section{Referências bibliográficas}

ALTHUSSER, L. P. Aparelhos ideológicos de Estado. 7. ed. Rio de Janeiro: Graal, 1998.

BASTIDE, Roger. Antropologia aplicada. Paris: Payot, 1971.

BOURDIEU, Pierre; PASSERON, Jean Claude. A reprodução. Elementos para uma teoria do sistema de ensino. Rio de Janeiro: Francisco Alves Editora, 1975.

BRANDĀO, Carlos R. (Org.). Pesquisa participante. 4. ed. São Paulo: Brasiliense, 1984.

CANDAU, Vera M. (Org.). Sociedade, educação e cultura(s): questões e propostas. Petrópolis: Vozes, 2002.

CARVALHO, Edgar A. As relações entre educação e os diferentes contextos culturais. Didática. São Paulo, n. 25, p. 19-26, 1989.

CONSORTE, Josildeth G. Culturalismo e educação nos anos 50: o desafio da diversidade. In: GUSMÃO, Neusa Maria M. de. Antropologia e educação. Interfaces do ensino e da pesquisa. Cadernos CEDES, n. 43. Campinas: Cedes/Unicamp, p. 26-37, 1997.

CUCHE, Denys. A noção de cultura nas Ciências Sociais. Bauru: Edusc, 1999.

CUNHA, Manuela C. da. Saberes locais, tramas identitárias e o sistema mundial na antropologia de Manuela Carneiro da Cunha. Sexta Feira - Antropologia, artes e humanidades, São Paulo: Pletora, n. 3, p. 80-91, outubro, 1998. (Entrevista concedida a Kiko Ferrite). 
DURHAM, Eunice. Cultura e ideologia. Dados — Revista de Ciências Sociais. Rio de Janeiro, v. 27, n. 1, p. 71-89, 1984.

FONSECA, Claudia. Educação sem terra. Um estudo de antropologia aplicada a um projeto de educação popular para um grupo de trabalhadores sem terra no interior de Minas Gerais. Tese (Doutorado) — Paris V, 1982, UFRGS, 1983.

. Quando cada caso NÃO é um caso. Revista Brasileira de Educação, n. 10, p. 58-78, jan/fev/abr, 1999.

GEERTZ, Clifford. A interpretação das culturas. Rio de Janeiro: Zahar Editores, (1973) 1978.

GUSMÃO, Neusa Maria Mendes de. Antropologia e Educação: origens de um diálogo. In: GUSMÃO, Neusa Maria Mendes de (Org.). Antropologia e Educação: interfaces do ensino e da pesquisa. Cadernos Cedes, Cedes/Unicamp, n. 43, ano XVIII. p. 8-25, dezembro de 1997.

. Linguagem, cultura e alteridade: imagens do outro. Cadernos de Pesquisa, n.107, p. 46-78, julho de 1999.

. Os filhos da Africa em Portugal. Antropologia, multiculturalidade e educação. Belo Horizonte: Autêntica, 2005.

KUPER, Adam. Cultura: a visão dos antropólogos. Bauru: Edusc, 2002.

L'ESTOILE, Benoit de; NEIBURG, Federico; SYGAUD, Ligia. Antropologia, impérios e estados nacionais: uma abordagem comparativa. In: L'ESTOILE, Benoit de; NEIBURG, Federico; SYGAUD, Ligia. (Org.). Antropologia, império e estados nacionais. Rio de Janeiro: Relume-Dumará, 2002. p. 9-37.

LOVISOLO, Hugo. Antropologia e educação na sociedade complexa. Revista Brasileira de Estudos Pedagógicos. n. 65, p. 56-69, jan./abr. 1984.

MICELI, Sergio (Org.). O que ler na Ciência Social brasileira (1970-1995). São Paulo: Editora Sumaré, ANPOCS; Brasília: Capes, 1999.

MONTERO, Paula. A marca de uma tradição. Revista de Antropologia - USP, São Paulo, v.46, n.2, p. 411-421, 2003.

ORTIZ, Renato. Diversidade cultural e cosmopolitismo. In: ORTIZ, Renato. Um outro território. Ensaios sobre a mundialização. 2. ed. São Paulo: Olho D’Água, 2000. p. 155-173.

. Estudos culturais. Tempo Social — Revista de Sociologia da USP. v. 16, n. 1, p.119127, junho de 2004 .

ROCHA-TRINDADE, Maria Beatriz. Sociologia das migraçôes. Lisboa: Universidade Aberta, 1995.

SANTAMARIA, Enrique. Do conhecimento de próprios e estranhos (disquisições sociológicas). In: LARROSA, Jorge; LARA, Núria Pérez de. (Org.). Imagens do outro. Petrópolis: Vozes, 1998.

SANTOS, Boaventura de Souza. A queda do Angelus Novus. Para além da equação moderna entre raízes e opções. Novos Estudos, n. 47, p. 103-124, março de 1997. São Paulo: Cebrap. 
SOUZA, Marcelo G.A. Educar para a tolerância e o respeito à diferença: uma reflexão a partir da proposta Escola Plural. In: CANDAU,Vera M. (Org.). Sociedade, educação e cultura(s). Questôes e propostas. Petrópolis: Vozes, 2002, p. 156-172.

TEIXEIRA, Beatriz de Bastos. Comunidades de escolas democráticas. In: GUSMÃO, Neusa Maria M de. Diversidade, cultura e educação: olhares cruzados. São Paulo: Biruta, 2003. p.47-82.

VALENTE, Ana Lucia F. Diálogos, monólogos e rituais: o que se diz sobre a interface antropologia/educação? Texto mimeografado, apresentado na reunião da ANPED de 1993.

VELHO, Gilberto. Individualismo e cultura: notas para uma Antropologia da sociedade contemporânea. 4. ed. Rio de Janeio: Jorge Zahar, 1997.

VIEIRA, Ricardo. Da multiculturalidade à educação intercultural: a antropologia da educação na formação dos professores. Educação, sociedades e culturas — Revista da Associação de Sociologia e Antropologia da Educação, Porto, n.12, p. 123-162, 1995.

. Ricardo. Ser igual, ser diferente. Porto: Profediçōes, 2000.

Recebido em 28 de março de 2008 e aprovado em 13 de junho de 2008. 